\title{
PEMANFAATAN CERITA RAKYAT JAWA TENGAH SEBAGAI PENGUATAN PENDIDIKAN KARAKTER DALAM PEMBELAJARAN BAHASA INDONESIA
}

\author{
Dewi Aprilia Sari, Sumarwati, Purwadi \\ Universitas Sebelas Maret \\ Surel: dewiaprils@student.uns.ac.id
}

\begin{abstract}
The purpose of this study is to describe the use of Central Java folklore as a strengthening of character building on Indonesian learning. This research is a case study which belongs to qualitative research and uses document as the data analysis. The object of this research is Central Java folklore, classroom observation result, lesson plan and syllabus of VII grade second semester, and the interview script of teacher and student. The technique of subject taking used is purposive sampling. The technique of collecting data is observation, interview, and document analysis. The validity test is using method triangulation and source triangulation. The data analysis technique is interactive analysis technique which consists of data reduction, data display, and building meaning and interpretation.The researcher found that, first, the intrinsic element of Central Javafolklore was encouraged by the characters in each story. Second, the value of character building on Central Javafolklore that existed in the characters. Third, the use of Central Javafolklore in Indonesian learning begins with planning in the form of lesson plan development based on the syllabus that has been prepared by the government. The planning, the implementation of learning begins from preparing the physical and psychological learners by providing stimulus in the form of motivation..
\end{abstract}

Keywords : intrinsic element, character education value, folklore

\begin{abstract}
ABSTRAK: Tujuan dari penelitian ini adalah mendeskripsikan pemanfaatan cerita rakyat Jawa Tengah sebagai penguatan pendidikan karakter dalam pembelajaran Bahasa Indonesia. Penelitian ini termasuk penelitian kualitatif yang menggunakan metode studi kasus dan menganalisis data berupa dokumen dengan objek kajian cerita rakyat Jawa Tengah, hasil observasi kelas, RPP dan silabus kelas VII semester genap, hasil wawancara dengan guru dan siswa. Teknik pengumpulan data berupa observasi, wawancara, dan analisis dokumen. Uji validitas data menggunakan triangulasi sumber dan metode. Teknik analisis data menggunakan teknik analisis interaktif. Unsur intrinsik cerita rakyat Jawa Tengah didorong oleh karakter tokoh. Nilai pendidikan karakter pada cerita rakyat Jawa Tengah yang terdapat pada tokoh dapat ditanamkan pada diri peserta didik.Pemanfaatan cerita rakyat Jawa Tengah dalam pembelajaran Bahasa Indonesia diawali dengan perencanaan berupa pengembangaan RPP berdasarkan silabus yang telah disusun oleh pemerintah. Pelaksanaan pembelajaran dimulai dengan menyiapkan fisik dan psikis peserta didik. Kendala-kendala tersebut tidak terlalu mengganggu proses pembelajaran karena guru dapat melakukan upaya-upaya agar pembelajaran dapat berjalan dengan lancar.
\end{abstract}

Kata kunci: unsur intrinsik, nilai pendidikan karakter, cerita rakyat

\section{PENDAHULUAN}

Perubahan etika generasi muda sudah mulai menurun, hal yang paling menonjol adalah terjadinya berbagai perbuatan dan perilaku yang cenderung 
mengabaikan nilai-nilai yang dianut masyarakat setempat. Perbuatan dan perilaku tersebut mengarah pada menurunnya moral dan kepribadian sehingga dikhawatirkan terjadinya krisis moral yang berkelanjutan. Penurunan kualitas moral kini menjalar dan menjangkiti Indonesia. Arus modernisasi memberikan perubahan yang cenderung mengarah pada krisis moral dan akhlak.

Salah satu persoalan yang dihadapi bangsa saat ini adalah terkikisnya kearifan lokal bangsa Indonesia. Nilai-nilai luhur yang dulu dijunjung kini telah tersingkirkan dan diganti dengan nilai-nilai yang lebih mengangungkan keberhasilan material tanpa memperhatikan etika dan nilai-nilai moral. Akibatnya adalah dalam berbagai bidang kehidupan, penyimpangan di bidang moral terjadi di mana-mana. Generasi muda mulai terasing dari budayanya sendiri. Oleh karena itu, kearifan lokal yang tersebar dan pernah melekat dalam kehidupan sehari-hari seluruh etnik di Indonesia perlu diangkat kembali ke permukaan, sehingga kekayaan peradaban bangsa dapat menjadi pedoman dalam kehidupan sehari-hari (Sumarwati, 2015).

Hal ini apabila dibiarkan akan membawa kehancuran bangsa. Berdasarkan fakta tersebut perlu dilakukan adanya penanaman etika kepada generasi muda yang dinilaisudahmengalamikrisis moral. Penanaman etika sejak dini sangat penting karena dengan adanya pemahaman akan etika, maka mereka akan berhatihati ketika bertingkah lakudanbersikapdalamkehidupansehari-hari.Penanaman etika yang dilakukan oleh nenek moyang pada masa lalu biasadilakukanmelalui tradisi lisan. Salah satu tradisi lisan tersebut adalah adanyacerita-cerita yang berkembangdari lisan ke lisan, yang dikenaldengancerita rakyat.

Sebuah studi tentang pemanfaatan cerita rakyat Jawa Tengah, yang berfokus pada latar belakangnya, nilai-nilai yang terkandung dalam cerita rakyat Jawa Tengah, dan manfaatnya belum diimplementasikan secara menyeluruh. Dengan demikian, penting untuk menggali nilai-nilai yang terkandung dalam cerita rakyat Jawa Tengah dan pengaruhnya terhadap pembelajaran Bahasa Indonesia di SMP. Studi saat ini berfokus pada: (1) unsur intrinsik cerita rakyat Jawa Tengah, (2) nilai-nlai pendidikan karakter cerita rakyat Jawa Tengah, dan (3) 
pemanfaatan cerita rakyat Jawa Tengah sebagai penguatan pendidikan karakter dalam pembelajaran Bahasa Indonesia di SMP.

\section{METODE PENELITIAN}

Penelitian ini merupakan penelitian kualitatif yang menggunakan metode studi kasus. Cakupan studi kasus menyelidiki banyak variabel dan banyak kondisi dalam sampel kecil. Penelitian ini dilaksanakan pada sampel kecil, yaitu mengkaji pembelajaran pada peserta didik kelas VII C SMP Negeri 1 Karang Malang. Teknik pengambilan subjek penelitian yang digunakan adalah purposive sampling Sumber data dalam penelitian ini antara lain, peristiwa pembelajaran pemanfaatan cerita rakyat, informan, dan dokumen. Peristiwa yang dijadikan sumber data dalam penelitian ini adalah pelaksanaan pembelajaran pemanfaatan cerita rakyat di kelas VII C SMP Negeri 1 Karang Malang Sragen. Infoman dalam penelitian ini adalah guru mata pelajaran Bahasa Indonesia dan peserta didik kelas VII C SMP Negeri 1 Karang Malang Sragen. Dokumen yang menjadi sumber data dalam penelitian ini antara lain: silabus dan RPP. Teknik pengumpulan data dilakukan dengan observasi, wawancara, dan analisis dokumen. Observasi dilakukan ketika proses pembelajaran pemanfaatan cerita rakyat di kelas VII C SMP Negeri 1 Karang Malang Sragen berlangsung dari pendahuluan, kegiatan inti, sampai penutup. Peneliti melakukan wawancara kepada guru mata pelajaran bahasa Indonesia dan dua siswa kelas VII C SMP Negeri 1 Karang Malang Sragen. Validitas data dilakukan dengan triangulasi data dan triangulasi metode. Teknik analisis data menggunakan analisis interaktif.

\section{HASIL PENELITIAN DAN PEMBAHASAN}

Cerita rakyat Jawa Tengah yang merupakan salah satu kearifan lokal yang perlu dilestarikan menjadi objek kajian dalam penelitian ini. Adapun cerita rakyat yang digunakan yakni: (1) Legenda Baturaden dari Karesidenan Banyumas, (2) Legenda Raden Kamandaka Karesidenan Kedu, (3) Legenda Dewi Lanjar dari Karesidenan Pekalongan, (4) Adipati Pandanarang dari Karesidenan Semarang, (5) Rara Mendut dari Karesidenan Pati, (6) Legenda Terjadinya Kota Surakarta 
dari Karesidenan Surakarta. Kearifan lokal yang dapat dijadikan sebaga alat untuk mendidik peserta didik menjadi insan yang cerdas, mulia, dan bermartabat. Hal ini dapat dilihat dari nilai-nilai yang terkandung dalam cerita rakyat.

Unsur dalam cerita memiliki keterkaitan antara keutuhan dengan isi materi cerita yang dapat diserap pembaca. Penemuan peneliti pada Cerita Rakyat Jawa Tengah sebagai berikut: (a) segi tokoh, cerita rakyat Jawa Tengah memiliki tokoh yang bergerak dalam perjuangan, baik perjuangan untuk rakyatnya maupun perjuangan dalam kebaikan diri sendiri, (b) tema cerita dalam cerita rakyat Jawa Tengah yaitu keagamaan, perjuangan, agama, (c) alur dari keenam cerita tersebut adalah alur maju, (d) setting tempat terikat, karena cerita terjadi di tempat yang jelas, dan (e) pesan cerita didominasi oleh budi pekerti dan nilai pendidikan karakter dari tokoh utama.

Penemuan penelitian mengenai unsur intrinsik juga ditemukan dalam hasil wawancara dan observasi di dalam kelas dengan guru dan siswa yang menjadi sampel. Responden menjawab daya tarik cerita didasarkan pada ketertarikannya terhadap tema dan penokohan yang mengandung nilia-nilai pendidikan karakter yang sangat kental. Hal ini konsisten dengan penelitian yang dilakukan oleh Sumarwati (2015) bahwa sebagai kearifan lokal cerita rakyat dianggap sebagai realitas yang mampu mengarahkan dan membimbing masyarakat pemiliknya dengan demikian akan ada beberapa pantangan yang tidak dapat dilanggar.

\section{Nilai-nilai Pendidikan Karakter dalam Cerita Rakyat Jawa Tengah}

Kementerian Pendidikan memaparkan delapan belas poinnilai pendidikan karakter yang berfungsi mengembangkan potensi peserta didik agar menjadi manusia yang beriman dan bertakwa kepada Tuhan Yang Maha Esa, berakhlak mulia, sehat, berilmu, cakap, kreatif, mandiri, dan menjadi warga negara yang demokratis serta bertanggung jawab. Hal tersebut dijabarkan dalam UU No. 20 tahun 2013 tentang sistem pendidikan nasional.

Cerita rakyat Jawa Tengah apabila dilihat dari keterkaitan dengan nilai pendidikan karakter, keenam cerita rakyat tersebut memiliki aspek-aspek yang kaitannya dengan nilai pendidikan karakter. Hal ini sesuai dengan tujuan 
Kurikulum 2013 yaitu penguatan pendidikan karakter sebagai pondasi kepribadian yang harus dimiliki siswa. Hal ini konsisten dengan penelitian yang dilakukan oleh Gusal (2015) mengkaji tentang pendidikan digunakan sebagai upaya untuk memajukan pertumbuhan nilai moral (kekuatan batin, karakter), dan pikiran. Proses pelaksanaannya melalui kegiatan terencana untuk membantu peserta didik dalam mengembangkan potensi yang maksimal pada dirinya, agar berperan secara efektif dalam kehidupannya sebagai pribadi yang baik.

Nilai yang terkandung dalam keenam cerita rakyat tersebut dapat diambil sebagai nilai positif yang merupakan sarana untuk penguatan pendidikan karakter. Nilai-nilai tersebut merupakan beberapa contoh yang ada pada diri setiap tokohnya. Nilai pendidikan yang ada dalam Kemendiknas (2011) mengemukakan 18 nilai pendidikan karakter yang semuanya sudah ada di dalam cerita rakyat Jawa Tengah dan perlu dikembangkan di sekolah. Nilai-nilai terseebut menjadi fokus analisis dalam cerita rakyat ini sebagai upaya penguatan pendidikan karakter. Berdasarkan pada nilai pendidikan karakter dari keenam cerita rakyat tersebut, nilai pendidikan karakter didominasi oleh nilai kerja keras dan perjuangan karena pada masa lampau seseorang cenderung ingin mempertahankan daerah kekuasaannya.

Perencanaan Pembelajaran Pemanfaatan Cerita Rakyat di SMP Negeri 1 Karang Malang

Persiapan yang harus dilakukan oleh seorang guru sebelum mengajar adalah menyusun Rencana Pelaksanaan Pembelajaran (RPP). RPP merupakan rencana pelaksanaan pembelajaran yang dikembangkan secara rinci serta mengacu pada silabus. Pada Kurikulum 2013 silabus telah disediakan oleh pemerintah sehingga tugas guru hanya mengembangkan RPP secara baik dan disesuaikan dengan perkembangan karakter peserta didik. Dalam mengembangkan RPP, guru mata pelajaran Bahasa Indonesia SMP Negeri 1 Karang Malang mengembangkan secara individu. Alasan RPP dibuat secara individu adalah agar RPP tersebut dapat disesuaikan dengan karakteristik peserta didik yang ada di sekolah tersebut. 
Hal tersebut bertujuan agar guru dapat memodifikasi pembelajaran secara tepat guna, terutama dalam hal merancang skenario pembelajaran, memilih materi ajar yang tepat, menentukan sumber belajar yang komprehensif, menyiapkan media pembelajaran yang bervariasi, serta menggunakan metode pembelajaran yang menarik serta disesuaikan dengan kebutuhan peserta didik. Dengan demikian, segala sesuatu yang dibutuhkan peserta didik dapat diatur oleh guru.

RPP yang disusun oleh guru mata pelajaran Bahasa Indonesia sudah mencantumkan (a) kegiatan pendahuluan; (b) kegiatan inti; dan kegiatan penutup yang telah dilengkapi dengan alokasi waktu serta pendidikan karakter. Kegiatan pendahuluan berfungsi untuk memberikan motivasi kepada peserta didik, apersepsi, dan mereview materi pelajaran sebelumnya. Kegiatan inti berfungsi untuk membahas materi inti pada pembelajaran hari itu. Kegiatan pendahuluan berfungsi untuk merefleksi dan menyimpulkan materi pembelajaran yang sudah dipelajari. RPP yang disusun oleh guru mata pelajaran Bahasa Indonesia memiliki keterkaitan dan keterpaduan. Dalam RPP Tujuan pembelajaran, kompetensi dasar dan indikator, materi pembelajaran dan penialaian disusun berdasarkan silabus yang ada. Sedangkan untuk komponen yang lain seperti metode pembelajaran, kegiatan pembelajaran, dan sumber belajar disusun guru dengan menambah dari sumber lain dengan melihat kondisi peserta didik.

Berdasarkan hasil wawancara dengan guru, ternyata guru masih kesulitan dalam menggunakan metode yang tepat dalam pembelajaran. Selain itu, materi ajar harus sesuai dengan silabus. Pada RPP yang disusun guru format dan sistematika RPP yang sudah disusun didasarkan pada aturan penyusunan RPP Kurikulum 2013. Hal ini dibuktikan dengan adanya komponen-komponen yang dikembangkan di dalam RPP sudah sesuai dengan Permendikbud Nomor 22 Tahun 2016 tentang Pembelajaran pada Pendidikan Dasar dan Pendidikan Menengah.

Pembelajaran Pemanfaatan Cerita Rakyat di SMP Negeri 1 Karang Malang Pelaksanaan pembelajaran merupakan proses interaksi antara peserta pelatihan dan pengajar menggunakan segala sumber daya yang sesuai dengan 
perencanaan yang telah dipersiapkan sebelumnya dalam rangka mencapai tujuan (Daryanto, 2012, 147-149). Observasi pelaksanaan pembelajaran pemanfaatan cerita rakyat Jawa Tengah di SMP Negeri 1 Karang Malang dilakukan sebanyak 3 kali pertemuan.

Pada pertemuan pertama guru menekankan pembelajaran pada aspek teori dan pengetahuan peserta didik. Pada pertemuan kedua guru mengarahkan pembelajaran pada pencapaian penguatan pendidikan karakter dengan memutarkan video cerita rakyat Legenda Adipati Pandanarang dan mengarahkan peserta didik membentuk kelompok untuk tugas bermain peran atau cerita berantai. Pada pertemuan ketiga, guru mengarahkan peserta didikuntuk memerankan karakter tokoh pada cerita rakyat Jawa Tengah.

Adapun kelas yang menjadi objek penelitian ini adalah kelas VII C. Peneliti melakukan observasi di kelas ini dengan pertimbangan kelas tersebut memiliki keunggulan di dalam pelaksanaan proses pembelajaran. Kompetensi dasar yang hendak dicapai adalah mengidentifikasi informasi tentang fabel/legenda daerah setempat dan menceritakan kembali isi fabel/legenda daerah setempat.

Pelaksanaan pembelajaran dimulai dengan kegiatan pendahuluan yang berisi pemberian motivasi kepada peserta didik. Hal ini bertujuan untuk menyiapkan fisik dan psikis peserta didik sebelum pelajaran dimulai. Guru juga memberikan motivasi kepada peserta didik dengan memberikan beberapa pertanyaan yang megandung nasihat dan semangat kepada peserta didik.

Kegiatan inti merupakan proses pembelajaran di mana guru memberikan fasilitas kepada peserta didik dengan memberikan buku paket dan LKS Bahasa Indonesia, dalam buku tersebut guru menunjukkan contoh cerita rakyat dan fabel yang ada di Jawa Tengah.Kegiatan menanya berisikan pertanyaan yang berkaitan dengan cerita rakyat Jawa Tengah, sebagian besar peserta didik belum mengetahui cerita rakyat apa saja yang ada, peserta didik cenderung mengenal cerita rakyat yang sudah terkenal saja. Kegiatan menanya ini dapat dilakukan oleh peserta didik tanpa kecuali, sehingga apabila ada materi pelajaran yang belum dimengerti, guru memberikan kesempatan bertanya sebanyak-banyaknya ke peserta didik. 
Kegiatan mengumpulkan data yang dilakukan oleh peserta didik dilakukan dengan cara menganalisis cerita rakyat melalui video dan teks yang telah disediakan oleh guru. Kegiatan tersebut didukung dengan pembuatan kelompok yang dilakukan oleh guru pada pembelajaran pemanfaatan cerita rakyat tidak secara rinci disebutkan dalam RPP. Pada pembelajaran yang dilakukan di kelas VII C, peserta didik menuliskan informasi yang didapat dari menganalisis cerita rakyat Jawa Tengah, hasil analisis tersebut berupa struktur intrinsik cerita rakyat dan nilai pendidikan karakter yang ada dalam cerita rakyat. Berdasarkan hasil analisis tersebut, peserta didik dapat mengambil nilai-nilai yang dapat diterapkan dalam kehidupan sehari-hari.

Kegiatan mengomunikasikan dilakukan pada pertemuan kedua yaitu menganalisis cerita rakyat. Meskipun kegiatan mengomunikasikan tidak terencana dalam RPP yang telah disusun, tetapi kegiatan pembelajaran tetap dapat berlangsung dengan baik. Pembelajaran pemanfaatan cerita rakyat di kelas VII C telah menerapkan pendekatan saintifik yaitu mengamati, menanya, mencoba, menganalisis data, dan mengomunikasikan hasil. Metode pembelajaran yang digunakan oleh guru adalah beragam, karena guru mengikuti alur pembelajaran dan menyesuaikan kebutuhan peserta didik.

Berdasarkan hasil observasi (lampiran 4 hingga 6), maka dapat disimpulkan bahwa proses pembelajaran pemanfaatan cerita rakyat di SMP Negeri 1 Karang Malang telah menerapkan pembelajaran menggunakan pendekatan saintifik sesuai dengan Kurikulum 2013. Hal ini mendorong motivasi, minat, kreativitas, inisiatif, inspirasi, kemandirian, dan semangat belajar peserta didik. Pembelajaran sudah menanamkan nilai-nilai pendidikan karakter, sehingga peserta didik dapat memahami cerita rakyat dan menerapkan nilai-nilai pendidikan karakter dalam kehidupan sehari-hari.

Kendala dan upaya yang dihadapi dalam pembelajaran pamenfaatan cerita rakyat

Pelaksanaan pembelajaran pemanfaatan cerita rakyat di kelas VII C SMP Negeri 1 Karang Malang yang telah dibahas sebelumnya memiliki beberapa 
kendala yang muncul selama pembelajaran berlangsung. Berikut pembahasan mengenai kendala-kendala yang telah ditemukan berdasarkan observasi: Kendala Guru

Berdasarkan hasil pengamatan, guru kurang terampil dalam menggunakan metode pembelajaran. Metode yang digunakan guru kurang memberikan motivasi kepada peserta didik dan tidak bisa meningkatkan semangat belajar. Pemilihan metode yang kurang relevan ini terkadang membuat peserta didik jenuh dalam mengikuti pembelajaran di kelas. Dalam hal ini, guru cenderung menggunakan metode yang sama dari awal sampai akhir pembelajaran. Upaya yang dilakukan oleh guru untuk mengatasi kendala tersebut adalah perlu diperhatikan agar teknik penyajian materi ajar tepat dan sesuai dengan materi yang akan diajarkan pada hari itu, sehingga peserta didik tidak akan merasa bosan.

Berdasarkan hasil wawancara, guru kesulitan untuk melakukan penilaian secara bersamaan. Penyebab guru kesulitan melakukan penilaian sikap adalah peserta didik yang dinilai terlalu banyak dan guru harus melakukan penilaian yang lain juga, yang mana dalam setiap kelas itu guru harus mengumpulkan tugas penilaian sekaligus, yaitu penilaian afektif, kognitif, dan psikomotorik. Upaya yang dilakukan guru untuk menagtasi kendala tersebut adalah dengan mengoptimalkan fungsi penilaian secara berkelompok bersama dengan guru yang lain. Dengan cara tersebut maka guru akan lebih mudah melakukan penilaian ini.

\section{Kendala Peserta didik}

Berdasarkan hasil observasi pembelajaran serta wawancara dengan guru dan peserta didik, minat baca peserta didik terhadap cerita rakyat yang panjang kurang. Hal ini terbukti ketika peserta didik ditugaskan untuk menganalisis unsur cerita rakyat, teradapat peserta didik yang masih berbicara dengan dengan teman sebangku. Upaya yang dilakukan guru adalah menghimpun berbagai informasi yang berkaitan dengan materi ajar yang telah dirumuskan, namun perlu diingat materi ajar yang dihimpun harus teruji terlebih dahulu secara ilmiah.

Berdasarkan hasil observasi dan wawancara, diperoleh data bahwa peserta didik tidak ingin bertanya langsung kepada guru mengenai materi pelajaran yang 
belum jelas, hal tersebut menyebabkan salah konsep dan peserta didik memilih untuk bertanya kepada teman sebangku. Upaya yang dilakukan guru untuk mengatasi adalah menciptakan suasana belajar yang kondusif, kelas yang kondusif dapat dapat mengantarkan peserta didik pada prestasi akademik maupun nonakademik. Peran guru sangat penting dalam pengelolaan kelas. Apabila guru mampu mengelola kondisi kelas yang baik, maka untuk mencapai tujuan pembelajaran yang telah dirumuskan tidaklah sulit.

\section{SIMPULAN}

Kelengkapan struktur telah ada dalam keenam cerita rakyat di Jawa Tengah. Analisis unsur intrinsik yang menyangkut tema, tokoh penokohan, alur, latar, dan amanat dalam cerita rakyat Jawa Tengah memiliki keterkaitan dengan keutuhan dan isi materi cerita yang mengandung nilai-nilai pendidikan karakter yang dapat diserap oleh pembaca. Unsur intrinsik yang menjadi daya tarik dari keenam cerita rakyat ini adalah tokoh dan penokohannya. Tokoh dan penokohan dalam keenam cerita rakyat ini memiliki keunikan berbeda-beda dan menunjukkan nilai karakter yang baik sehingga peserta didik dapat menerapkan nilai karakter tersebut dalam kehidupan sehari hari.

Dilihat dari observasi yang dilakukan di kelas VII C, peserta didik yang memerankan tokoh pada saat cerita berantai sangat mendalami dan memerankan watak tokoh dengan baik. Selain itu, dari hasil wawancara yang dilakukan dengan guru mata pelajaran Bahasa Indonesia dan peserta didik mengatakan cerita rakyat ini baik dan layak untuk dijadikan bahan ajar karena mengangkat kearifan lokal dan sebagian cerita rakyat berasal dari luar daerah Kabupaten Sragen. Meskipun demikian, cerita rakyat tersebut tetap bisa digunakan sebagai bahan ajar dan diterapkan dengan baik dalam proses pembelajaran di dalam kelas. 


\section{DAFTAR PUSTAKA}

Daryanto, Rahardjo M. (2012). Model Pembelajaran Inovatif. Yogyakarta: Gava Media.

Gusal, La Ode. (2016). "Nilai-nilai Pendidikan dalam Cerita Rakyat Sulawesi Tenggara Karya La Ode Sidu”. Jurnal Humanika. 16 (1), 1-18.

Kemendiknas .(2011). Desain Induk Pendidikan Karakter.Jakarta: Kementerian Pendidikan Nasional.

Sumarwati. (2015). The Traditional Dhukutan Ceremony in Tawangmangu, Karanganyar Regency, Indonesia. International Indonesia Forum. Working Paper Series 7. 